\title{
Investigation the effectiveness of the mind simulation model on reducing stress and increasing cognitive flexibility in adult with stuttering disorder
}

\author{
Mohammad Ehsan Taghizadeh ${ }^{1}$, Nemat Allah Yarollahi ${ }^{2}$, Zahra Bahrami ${ }^{3}$ \\ 1. Associate professor of Payam-e-Noor University, Tehran, Iran \\ 2. MSc in clinical psychology, Shahed University, Tehran, Iran. \\ 3. MSc in clinical psychology, Payam-e-Noor University, Tehran, Iran. \\ Corresponding Author, E-mail: bahrami20.psy@gmail.com
}

\begin{abstract}
Introduction: Many stutterers suffer from excessive stress and deficit in cognitive inflexibility. Mind Simulation Model is a new treatment proposed for stuttering and its related problems.

Aim: This study aimed to investigate the effectiveness of mind simulation model on stress reduction and cognitive flexibility enforcement in adult with stuttering disorder.

Method: This was a quasi-experimental study with a pre-test/ post-test design and a control group. The number of 30 stutterer participants referring to Tavanmandsazan-e-Zehn Clinic were selected through available sampling method and put randomly into the experimental and control groups. After measuring basic levels of stress and cognitive flexibility of all participants, the experimental group received mind simulation therapy, while the control group received no intervention. Finally, both groups completed the post-tests.
\end{abstract}

Results: Results of MANCOVA analysis showed that mind simulation model could significantly reduced stress $(\mathrm{P}<0.01)$ and improved cognitive flexibility $(\mathrm{P}<0.05)$ compared to the control group.

Conclusion: given these findings, it can be claimed that mind simulation model can significantly treats stuttering and its related problems in adults through mind empowerment.

Keywords: Cognitive flexibility, mind simulation model, stress, stuttering 


\title{
بررسى اثربخشى مدل شبيهازى ذهن بر كاهش استر س و افزايش انعطافيذيرى شناختى بزرىسالان مبتلابه لكنت زبان
}

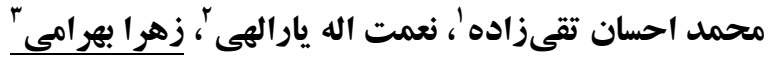

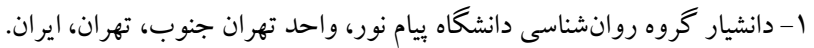 \\ r- كارشناسى ارشد روانشناسى بالينى، دانشكاه شاهد، تهر ان، ايران.

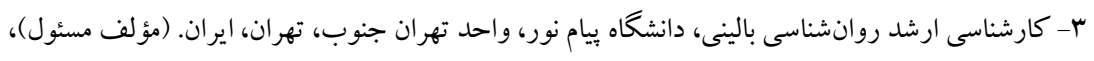

جكيده

مقدمه: بسيارى از افراد داراى لكنت، استرس فراوانى را متحمل شده و انعطاف يذيرى شناختى آنان نيز دجار نقص است. يكى از

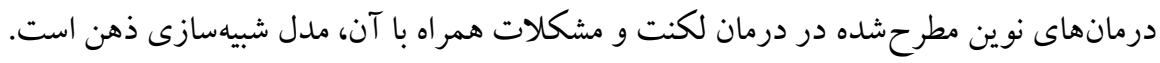
هدف: هدف از يُوهش حاضر، بررسى اثربخشى مدل شبيهسازى ذهن بر كاهش استرس و افزايش انعطاف يذيرى شناختى افراد مبتلابه لكنت بود. روش: اين يزوهش از نوع نيمه آزمايشى با طرح بيش آزمون-بِ آزمون و گروه كنترل بود. تعداد ·ب نفر از بزركُسالان مبتلابه

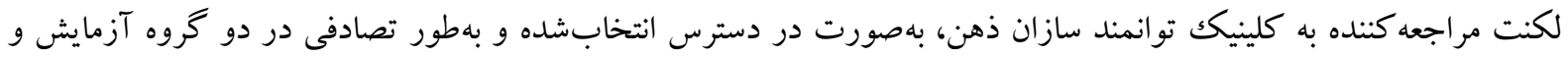

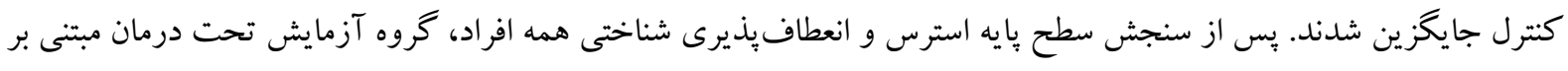

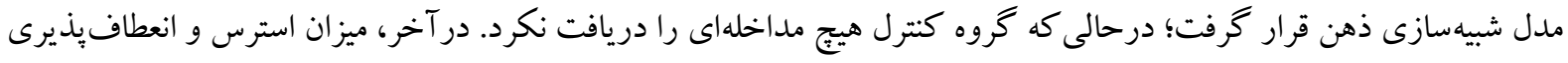

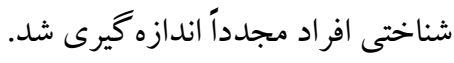
يافته ها: نتايج تحليل مانكووا نشان داد كه مدل شبيهسازى ذهن در مقايسه با گروه كنترل، بر كاهش استرس (1...•P<) و افزايش

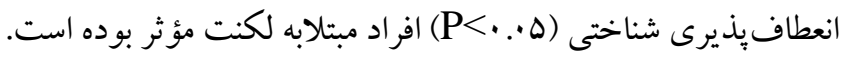
نتيجه كيرى: با توجه به نتايج اين يزٔوهش، مى توان كفت كه مدل شبيهازى ذهن مى تو اند لكنت زبان و مشكلات همراه با آن را

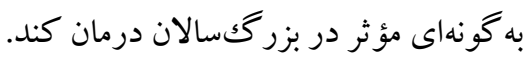
كليد وازهها: استرس، انعطافيذيرى شناختى، لكنت زبان، مدل شبيهازى ذهن 
فصاحت اغلب در مواقع قرائت شفاهى، آواز خواندن يا صحبت كردن با حيوانات خانكى و اشياء بى جان ديده

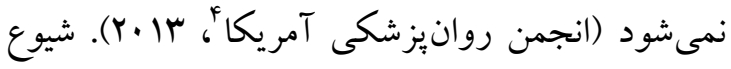

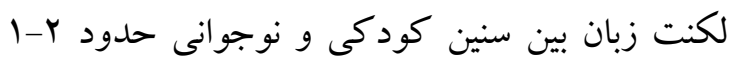
درصد است كه نسبت ابتلاى پِران به دختران ب به 1

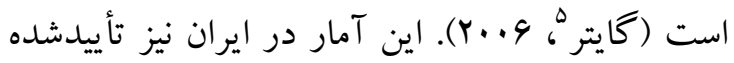

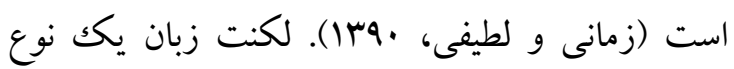

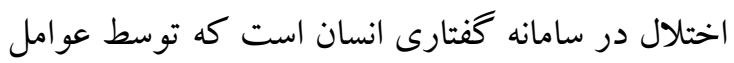
مختلفى ايجاد مىشود و رفتهرفته از حالت خفيف فاصله گرفته و تشديد مىيابد. تمامى سامانه لهاى شناختى و رفتارى ما ازجمله زبان تا سن دهسالكى شكل

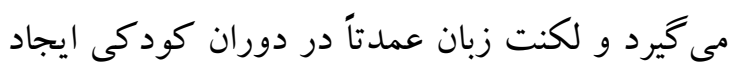
مىشود، يعنى زمانى كه هنوز سامانه كفتارى شكل

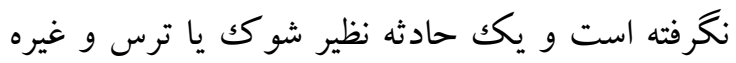

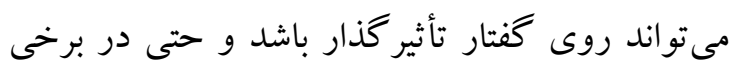
كود كان عادتهاى بد گفتارى يا تقليد و تعامل با فرد يا افر اد لكنتى مى تواند كودك را دوجار لكنت زبان كند و به دليل عدم تكامل ذهن و سامانه گفتتارى در مسير شكل گيرى گفتار كودك اختلال ايجاد مىشود و و كودكك نمىتواند مهارتهاى گفتتارى خود را كامل كند (تقىزاده و بيگدلى شاملو، 19 19). ازاينرو،

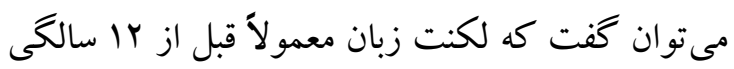
نمود مى يابد، هرجند كه در اكثر موارد از هجدهماهكى

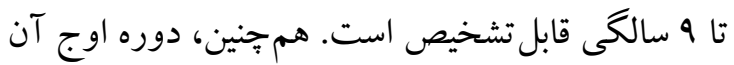
بين r تا ه/r سالكى و ه تا V سالكى است.

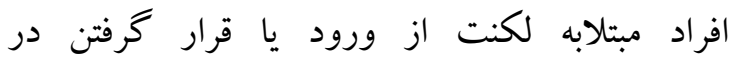
موقعيتهايى كه نيازمند كفتار است، دورى مى كنند و

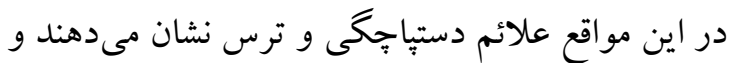
شدت لكنت با عواطفى هم جون خجالت، ناميدى و و

\footnotetext{
${ }^{4}$ American Psychiatric Association (APA)
} ${ }^{5}$ Guitar

\section{مقدمه}

رفتار اجتماعى بايه و اساس زندكى هر فرد را تشكيل مىدهد. زبان، يكى از كار آمدترين و مؤثرترين ابزارها جهت بيان افكار انسان و از مهمترين عناصر براى برقرارى يكك رابطه انسانى و اجتماعى است. درواقع زبان نوع عالى و مشتر ك رفتار اجتماعى است (احدى،

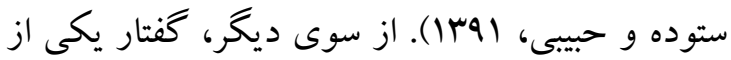
نمونههاى عينى و قابلشنيدن زبان است كه در ايجاد ارتباط افراد با يكديخر از اهميت زيادى برخئ وخوردار است. گفتار و زبان هر يكك ممكن است جداكانه يا باهم به دلايل مختلف دجار آسيبهايى به درجات كوناكون شوند و مسير ارتباطى اصلى انسان را مختل نمايند (فرازى و همكاران، rarr). يكى از مهمترين و متداولترين اختلالات تكلمى،

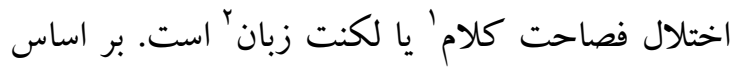
ينجمين راهنماى تشخيصى و آمارى اختلالات روانى

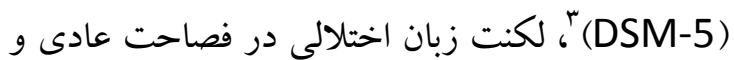
الكوى زمانى كفتار است كه فرد را در كسب مهارتهاى متناسب با سن و مهارتهاى زبانى دجار مشكل مى كند. اين آشفتكى باكذشت زمان ادامه

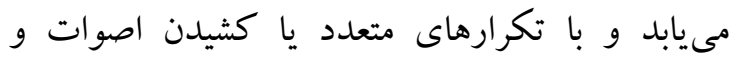
هجاها و ساير انواع عدم فصاحت كلامى شامل كلمات

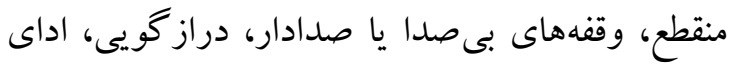
كلمات با فشار جسمى بيشازحد و تكرار كامل كلمات تككهجايى مشخص مىشود. اين آشفتكى فصاحت با بيشرفت تحصيلى و شغلى يا ارتباطات اجتماعى فرد تداخل دارد. شدت اين آشفتخى از موقعيتى به موقعيت ديخر فرق مى كند و در مواقعى كه فشار و هيجان وجود دارد بيشتر است. آشفتكى موسى موريك

\footnotetext{
${ }^{1}$ fluency disorder

2 stuttering

${ }^{3}$ Diagnostic and Statistical Manual of Mental Disorders (DSM)
} 
و به توانايى فرد براى در نظر گرفتن همزمان

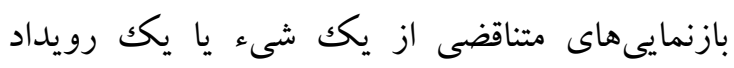

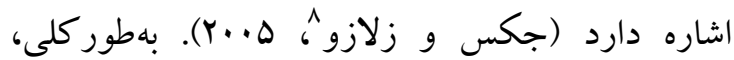

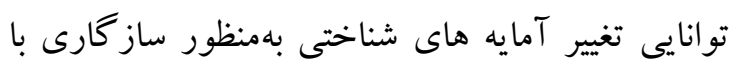

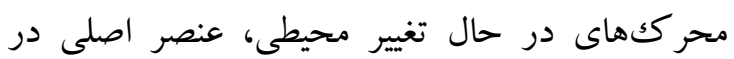
تعاريف عملياتى انعطاف يذيرى شناختى است (دنيس و

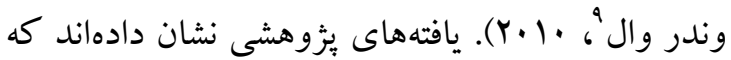

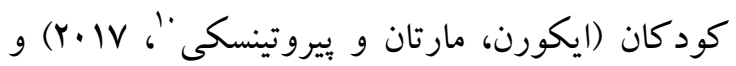

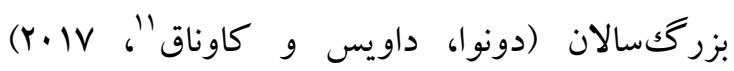
مبتلابه لكنت زبان در به كارگيرى و تغيير ׳" مؤثر توجه از يكك بعد به بعد ديخر يكك محرك يـ يا رويداد

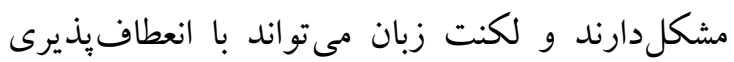
شناختى ضعيفتر و بهتبع آن، بروز نقص در تكاليف شناختى همراه باشد كه اين موارد خود مى تواند بر بر برون بايدار ماندن لكنت نقش داشته باشند. امروزه اقدامات مختلفى براى درمان افراد داراى اختلال

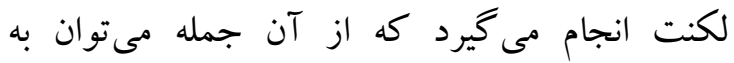
كفتاردرمانى، درمانهاى رفتارى، شكلدهي هيى روانى

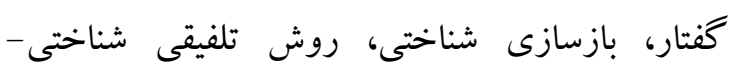
كفتارى، دارودرمانى، طب سنتى، نصب بروتز حنجره، هيينوتيزم و ساير اشاره كرد. باوجوداين، تلاشهاى صورت كرفته در درمان لكنت همواره موفقيت آميز نبوده و يا نتايج درمان پِ از جندى بـ باز گشت كرده

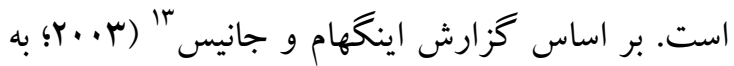

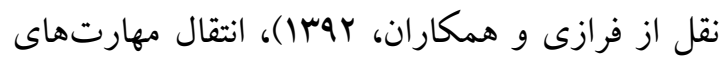
نظاممند روانى كفتار در طول جلسات درمانى مفيد بوده، اما حفظ و تداوم روانى ايجاد شده براى بلندمدت به سبب قطع شدن محرك (الكوى گفتارى ارائهده) بهندرت امكانيذير است.

\footnotetext{
${ }^{8}$ Jacques, \& Zelazo

${ }^{9}$ Dennis \& Vander Wal

${ }^{10}$ Eichorn, Marton., \& Pirutinsky

${ }^{11}$ Doneva, Davis, \& Cavenagh

${ }^{12}$ shifting

${ }^{13}$ Ingham, \& Janis
}

ترس از ارزيابى اجتماعى منفى مرتبط است. آنها

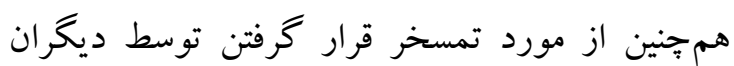
نكران هستند. افكار و باورهاى نادرست ازجمله احساس اجبار درونى براى كنترل لكنت، ترس از احتمال بروز لكنت در هرلحظه و همجهنين تصور دقت

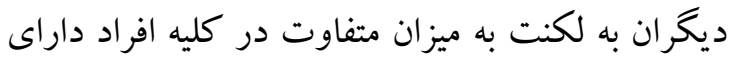
لكنت وجود دارد. بهاينترتيب، يكى از مشهودترين و وخيم ترين ييامدهاى لكنت، ايجاد اضطراب- بهويزه در

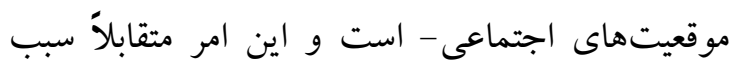
تشديد و استمرار لكنت مىشود (آيورجج و همكاران، 19.19). استرس و اضطراب عامل تشديدكننده لكنت زبان است و افزايش لكنت زبان، خود افزايش استرس را به همراه دارد (توزنده جانى و همكاران، ·al1). بنابراين، هر موقعيتى مى تواند براى فرد استرسزا بوده و

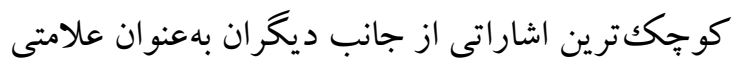
از ارزيابى منفى براى فرد قلمداد شده و جنين برداشتى دوباره باعث تشديد استرس در فرد مىشود. افراد داراى لكنت زبان توانايى مديريت اين استرس

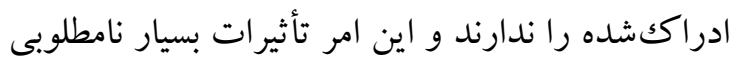
بر سلامت روانى و كاركرد فردى و اجتماعى (مانند محدوديت هاى انتخاب شغل) افراد مبتلا دارد (كاكوئى

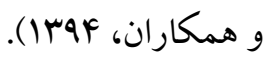
از سوى ديخر، وقتى عامل استرسزا زندگى انسان را تحت تأثير قرار دهد، حالات هيجانى و تفكر فيزيولوزيكى فرد از حالت بهنجار و متعادل خود خارجشده و فعاليتهاى شناختى نيز آسيبيذير مى گردد. بهطور مشخص، يكى ديخر از مشكلات افراد

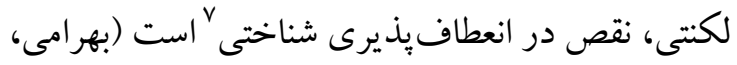

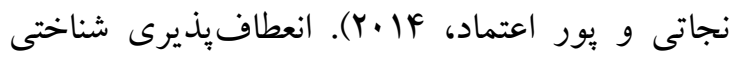
بهنوان ويز گى عمده شناخت انسان توصيف شده است

\footnotetext{
${ }^{6}$ Iverach

${ }^{7}$ cognitive flexibility
} 
نيز كار آمدى اين مدل را در درمان مشكلات همراه با لكنت نشان دادهاند. براى مثال، شير خدايى، تقىزاده و

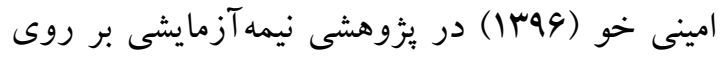

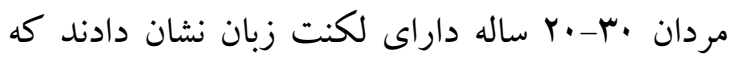
مدل درمانى شبيهسازى ذهن در مقايسه با گروه كنترل بهطور معنادارى ترس از حرف زدن افراد داراى لكنت را كاهش و اعتمادبهنفس آنان را افزايش داد. صانعى،

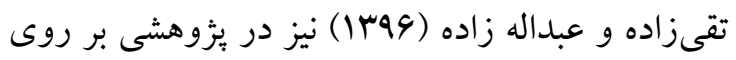

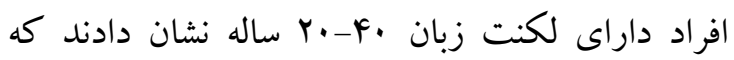
مدل درمانى شبيهسازى ذهن در مقايسه با گروه كنترل بهور معنادارى بر تقويت تنظيم هيجانات و تفكر مثبت مبتلايان مؤثر واقع شد.

بهاينترتيب، با توجه به نقش استرس و نقص برخى كاركردىهاى شناختى در بروز و تداوم اختلال لكنت و آسيبها و ويامدهاى فردى و بين فردى آن؛ و و همجنين با توجه به اينكه بسيارى از درمانهاى كنونى بهور كامل اثربخش نبوده و يا نتايج درمانى آنها پس بس بـ از مدتى باز گشت مى كند (تقىزاده و بيخدلى شاملو،

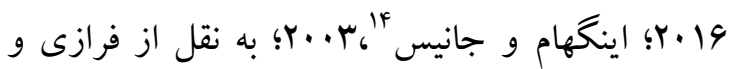

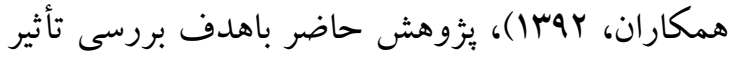

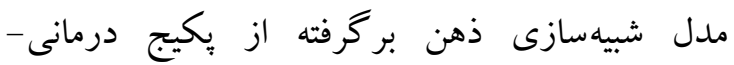
آموزشى تقىزاده در درمان مشكلات استرس و و برد انعطاف يذيرى شناختى افراد مبتلابه لكنت زبان انجام

يزوهش حاضر از نوع نيمهآزمايشى با طرح بيش آزمون -ِّس آزمون همراه با گرووه كنترل است.

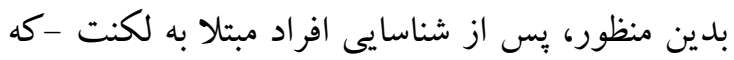
بر اساس ارزيابى متخصص اين حوزه مبتلا به لكنت زبان تشخيص داده شدند- و انتخاب نمونه و انجام

\footnotetext{
${ }^{14}$ Ingham, \& Janis
}

يكى از درمانهاى جديد و نويدبخش در درمان مؤثر و بدون بازگشت لكنت زبان، مدل شبيه سازى ذهن لهن تقىزاده است. شبيهسازى ذهن، دانشى براى دستيابى به اطلاعات ذهن انسان است. شبيهسازى ذهن يعنى شبيهسازى اطلاعات ذهن و تبديل آن به اطلاعات مادى و فيزيكى كه با مشاهده آن بهوسيله اين دانش نوين

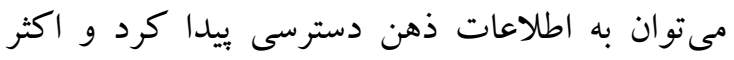
تغييرات را بهسرعت در ذهن ايجاد كرد (تقىزاده و

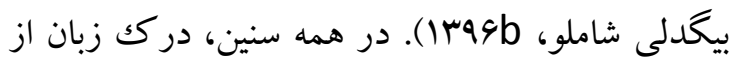

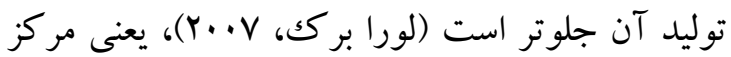
اصلى زبان، ذهن انسان است. از ديدكاه تقىزاده لكنت زبان درصورتى كه در شرايطى كه (I Iraga) جسم آسيب نديده باشد (مثل تصادف، ضربه، بيمارى جسمى و آسيب ديدن اعضاى گفتارى)، مسئلهاى كاملاً ذهنى و روانى است. افراد داراى لكنت نمى تو انند با نغاه كردن به كفتار افراد نرمال و حتى داراى مهارت كفتارى بالا از آنها بياموزند. طبق اين ديدگاه، علت

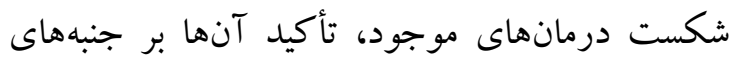
فيزيكى و مكانيكى كفتار است. حال براى ايجاد مهارتهاى كفتارى بايد فرايند شكل گيرى آنها را بهصورت طبيعى بازسازى كرد؛ يعنى شبيهازى شكل گيرى مهارت كفتارى. با استفاده از شبيهسازى ذهن و زبان برنامهنويسى ذهن مىتوان با طراحى و اجراى برنامه درمانى و آموزشى، با

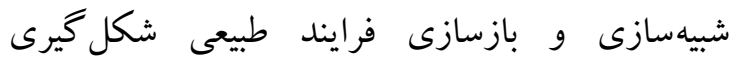
مهارت، جنبههاى مختلف مهارت گففتار را به افراد داراى لكنت آموزش داده و لكنت آنها را به شكل قطعى درمان كرد (تقىزاده و بيگدلى شاملو، و

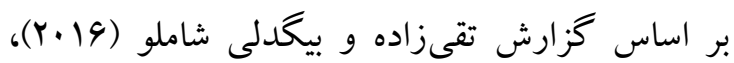

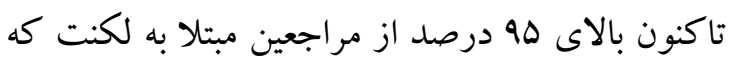
تحت درمان شبيهسازى ذهن قرارگرفتهاند، به درمان عالى و خوب رسيدهاند. هم جنين، يزوهش هاى ديخرى 
r) ابتلاى افر اد به عقبماندگى ذهنى، اتيسم، فلج مغزى و داراى تجربه سكته شديد مغزى

ابزار در اين ئزوهش بهمنظور جمع آورى دادهها و اجراى ئزوهش از ابزارهاى زير استفاده شد:

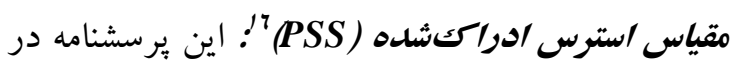

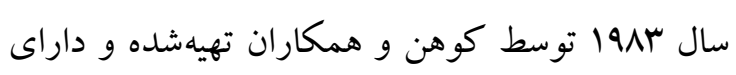

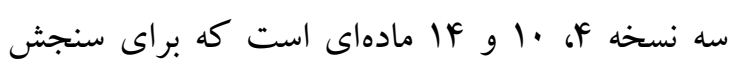
استرس عمومى ادراككشده (شامل افكار و احساسات درباره حوادث استرسزا، كنترل، غلبه، كنار آمدن با فشار روانى و استرسهاى تجربهشده) در يكك ماه كذشته به كار مىرود. همجنين، اين مقياس عوامل خطرزا در اختلالات رفتارى را بررسى كرده و فرايند روابط تنشزا را نشان مىدهد. نمره خذارى اين ابزار بهصورت ليكرتى ه درجهاى است و هر ماده داراى

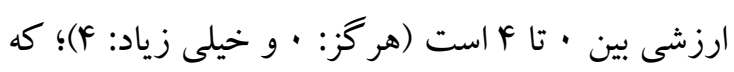
نمرات بالاتر نشان از ميزان استرس ادراككشده بيشتر

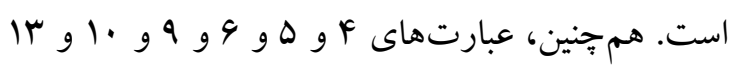
بهور معكوس نمره گذارى مىشود. بدين ترتيب، كمترين امتياز كسبشده صفر و بيشترين امتياز كسبشده D9 است و نمره بالاتر نشانه استرس

$$
\text { ادراككشده بيشتر است. }
$$

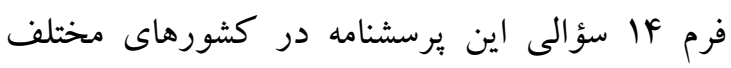

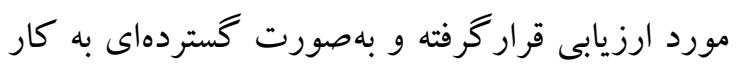

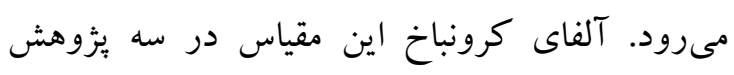

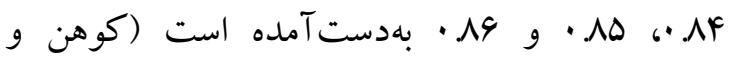
همكاران، ra/1). بهروزى، شهنى ييلاق و بورسعيد

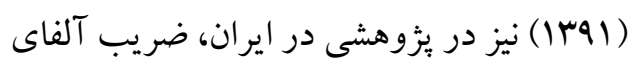
كرونباخ و تصنيفى برسشنامه حاضر را به ترتيب س V. • و .VF

${ }^{16}$ Perceived Stress Scale (PSS)
ييش آزمونهاى اوليه جهت كنترل نمرات سطح بايه

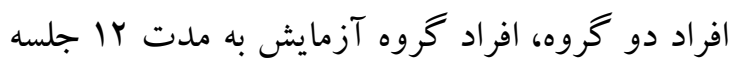

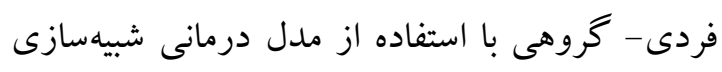
ذهن تحت درمان قرار گرفتند و افراد گروه كنترل در برد

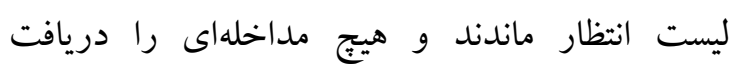
نكردند. در آخر، نمرات بس آزمون دو گروه بهمنظور ماند تعيين اثربخشى مدل درمانى شبيه سازى ذهن با يكديخر مقايسه كرديد. جامعه آمارى يُزوهش حاضر متشكل از تمامى افراد

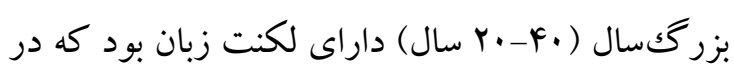
سال وها از سراسر كشور به كلينيك توانمند سازان

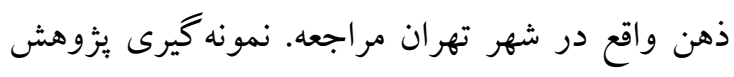
حاضر بهصورت در دسترس بود. به اين منظور، با توجه

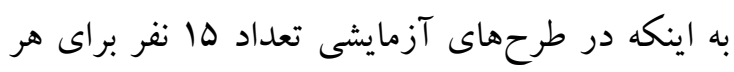

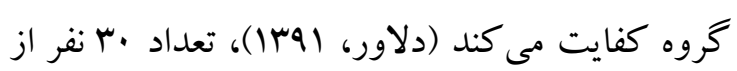

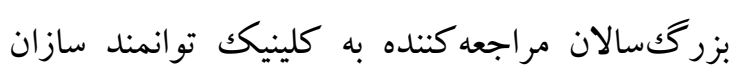
ذهن كه توسط ارزيابىهاى متخصص به لكنت متوسط تا خيلى شديد مبتلا بودند، بهصورت در دسترس

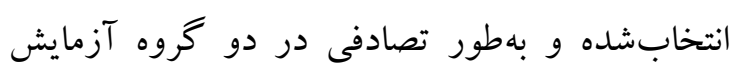
(درمان) و كنترل (هر كدام ها نفر) جايخزين شدند إند. لازم به ذكر است، معيارهاى ورود و خروج افراد به اين شرح بود:

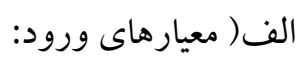
( ) مبتلا به لكنت زبان

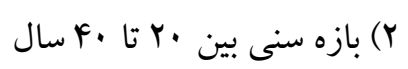

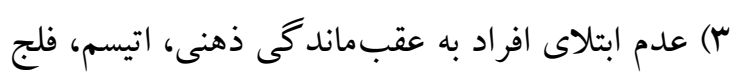

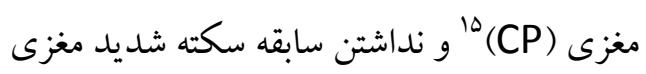

$$
\text { ب) (ب) معيارهاى خروج: }
$$

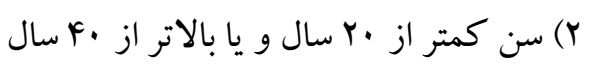

\footnotetext{
${ }^{15}$ cerebral palsy
} 
آشنايى بيشتر با لكنت و درمانهاى رايج و ناموفق، افراد در بهصورت اختصاصى و گروهى با درمان نوين شبيهسازى ذهن و موفقيت اين درمان در رفع لكنت مبتلايان آشنا مىشوند. از جلسه دوم تا جلسه آخر، در ابتداى هر جلسه ميزان بيشرفت مراجع بر آورد شده و تكاليف جلسه قبل مرور مىشد. بِ از اجراى روند

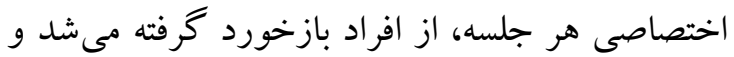

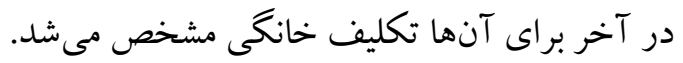
لازم به ذكر است تجزيهوتحليل دادهها با استفاده از

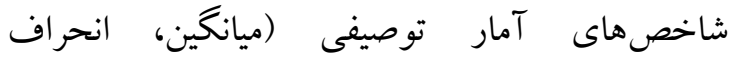
استاندارد) و آمار استباطى (تحليل كوواريانس رانس

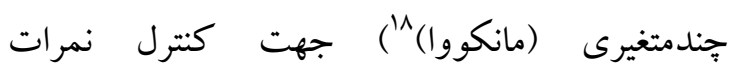
بيش آزمون گروههاى آزمايش و كنترل و مقايسه

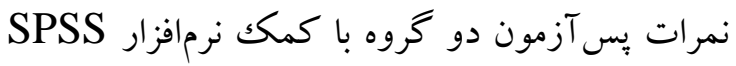
نسخه بr انجام شد.

يافتهها هر كدام از گروهها شامل ها نفر بودند. ميانگين سنى

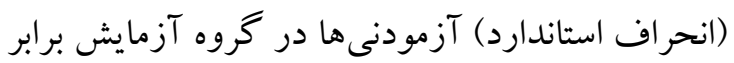

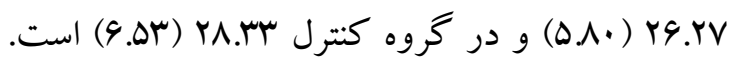
در گروه آزمايش تعداد سا نفر مرد و r نفر زن بوده كه از اين ميان، به ترتيب V و 1 نفر مجرد و متأهل

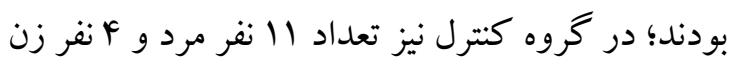
بودند و تعداد 4 آنان مجرد و 9 نفر متأهل بودند. هم جنين، در مورد سطح تحصيلات نمونه يزوهش بايد

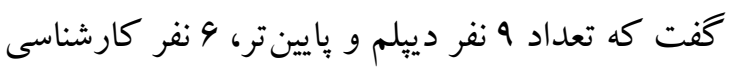
و r نفر كارشناسى ارشد بودند. لازم به ذكر است كه مقايسه متغيرهاى توصيفى يادشده، تفاوت معنادارى را بين دو گروه با نشان نداد.

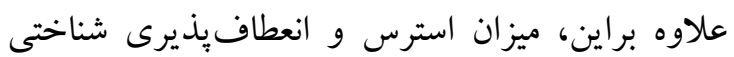
افراد دو گروه ييش از شروع درمان (ييش آزمونها) و

${ }^{18}$ Multivariate Analysis of Covariance (MANCOVA)
حاضر بهمنظور سنجش استرس عمومى ادراككشده در افراد دو گروه بيش و بِ از انجام درمان استفاده شد.

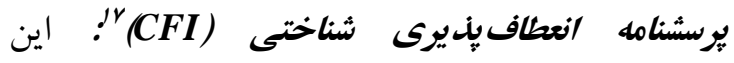

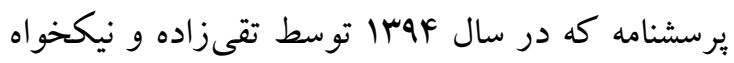

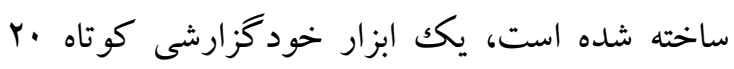
عبارتى است و تلاش دارد تا سه جنبه انعطافيذيرى شناختى شامل: الف- انعطافيذيرى در موقعيتهاى

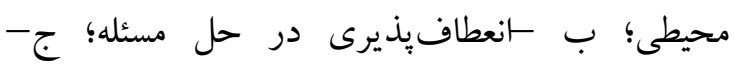

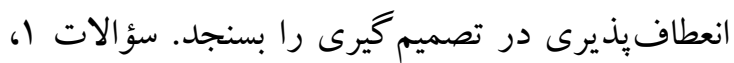

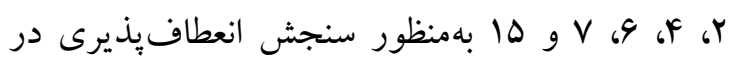

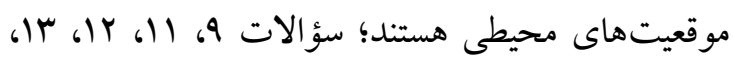
ا انعطافيذيرى در حل مسئله IV IV IF

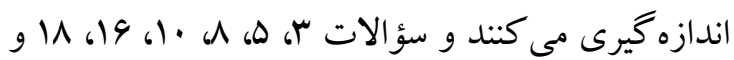
• r نيز مربوط به انعطاف يذيرى در تصميم گيرى است.

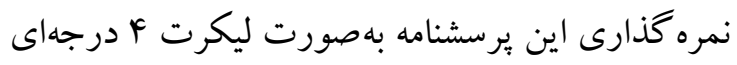

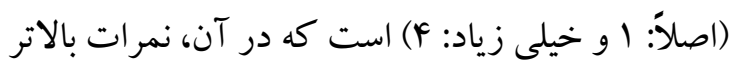
نشاندهنده انعطافيذيرى شناختى بيشتر است. اين برسشنامه را مى توان با مقاصد مختلف در كار بالينى و

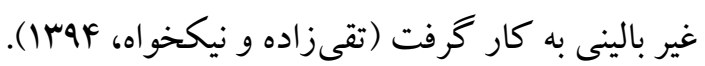
تقىزاده و نيكخواه (Iraf) در يزوهش خود آلفاى كرونباخ يرسشنامه مذكور را برابر كردند. همجنين، ضريب آلفاى كرونباخ در خرده مقياسهاى انعطافيذيرى در موقعيتهاى محيطى، انعطافيذيرى در حل مسئله و انعطافيذيرى درى

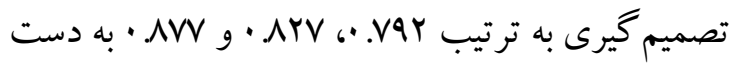

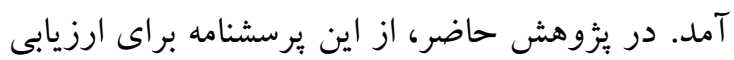

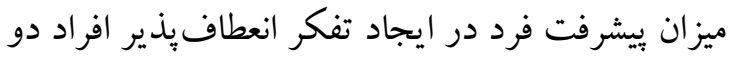
گروه بيش و بِ از درمان استفاده گرديد. يروتكل درمان (مدل شبيه سازى ذهن بركرفته از پيكيج درمانى - آموزشى لكنت زبان تقىزاده): در جلسه اول بعد از آشنايى با تعداد جلسات و روند درمان و ورسيح

${ }^{17}$ Cognitive Flexibility Inventory (CFI) 


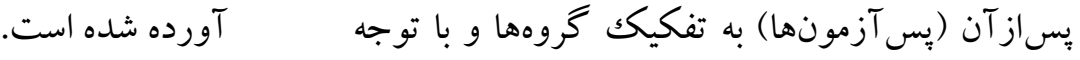

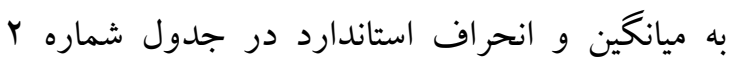

جلسات درمان و محتواى هر جلسه در جدول زير آمده است: جدول ا. خلاصه جلسات درمان

\begin{tabular}{|c|c|}
\hline محتوى جلسات & جلسات \\
\hline ريتميك كشخى كذى -تصويرسازى ذهنى & جلسه او r \\
\hline 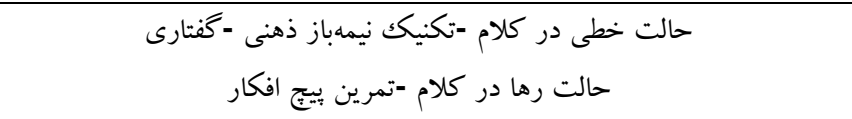 & جلسه برو F \\
\hline درمان تيكك سروصورت -درمان وسوان كلامى -مديريت بر استرس فكرى و كلامى & جلسه هو 4 \\
\hline 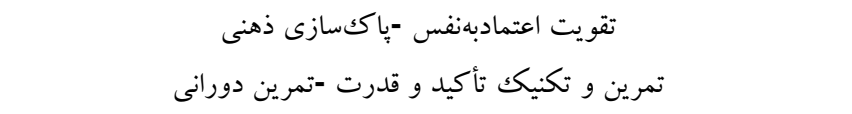 & جلسه Vو ^ \\
\hline 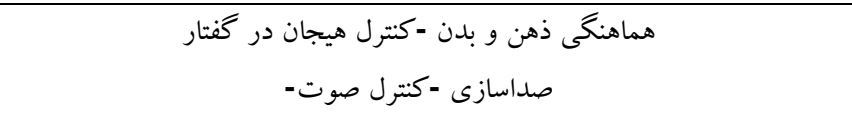 & جلسه 99 . 1 \\
\hline 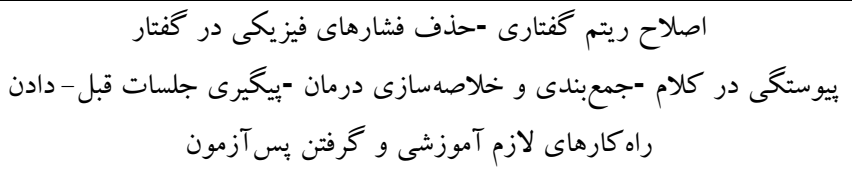 & جلسه ||و r| \\
\hline
\end{tabular}

جدول r. نمر ات دو كروه در متغيرهاى استرس و انعطاف يذيرى شناختى پِيش و پِ از مداخلات

\begin{tabular}{|c|c|c|c|c|}
\hline ميانكين (انحراف استاندارد) & كروه & 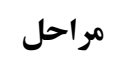 & \multicolumn{2}{|l|}{ متغير } \\
\hline$(f . r q)$ rq.A. & آزمايش & \multirow{2}{*}{ بيش آزمون } & \multirow{4}{*}{\multicolumn{2}{|c|}{ استرس ادراككشده }} \\
\hline (G.rr) rI.F. & كنترل & & & \\
\hline$(F . I V)$ YV.YV & آزمايش & \multirow{2}{*}{ 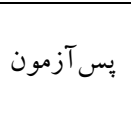 } & & \\
\hline$(F . g 4) \mu 1 . q$. & كنترل & & & \\
\hline$(Y . \mu \Lambda) 10.9 \mathrm{~V}$ & آزمايش & \multirow{2}{*}{ ي بيش آزمون } & \multirow{4}{*}{ انعطاف يذيرى در } & \multirow{13}{*}{ 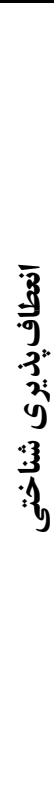 } \\
\hline$(Y . V \Delta) \mid \Delta . \Delta r$ & كنترل & & & \\
\hline$(r . \wedge) \mid 9 . \wedge$. & آزمايش & \multirow{2}{*}{ آزمون } & & \\
\hline$(Y . V F) \mid F . q r$ & كنترل & & & \\
\hline$(Y . r \cdot)$ Y... & آزمايش & & \multirow{4}{*}{ انعطاف پذيرى در } & \\
\hline$(r . q r) r \cdot \Lambda \cdot$ & 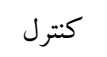 & & & \\
\hline 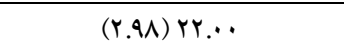 & آزمايش & \multirow{2}{*}{ 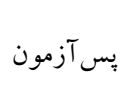 } & & \\
\hline r. (Y.qT) & كنترل & & & \\
\hline (Y.rT)Y... & آزمايش & \multirow{2}{*}{ ي بيش آزمون } & \multirow{4}{*}{ 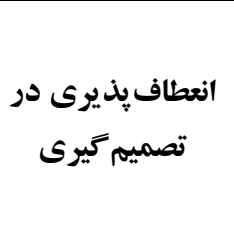 } & \\
\hline r. & كنترل & & & \\
\hline (Y.FG) YI.Vr & آزمايش & \multirow{2}{*}{ يس آزمون } & & \\
\hline$(r . \Delta q)$ ।q.r. & كنترل & & & \\
\hline$(9 . \cdot r) \Delta \Delta .9 \mathrm{~V}$ & آزمايش & يِش آزمون & كل & \\
\hline
\end{tabular}




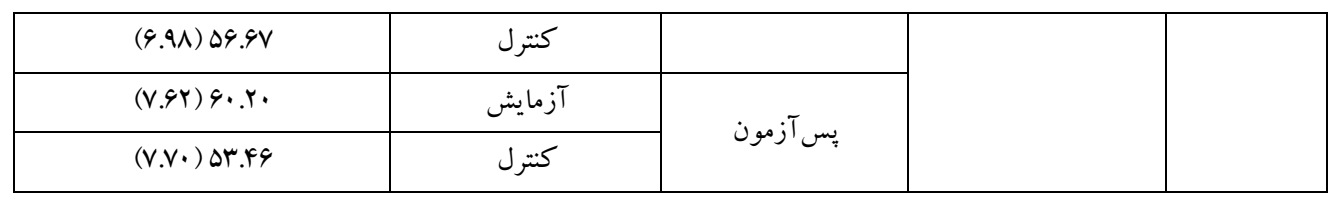

بيش آزمونها و متغير مستقل (روش درمان) در مرحله ״س آزمون موردبررسى قرار گرفت. نتايج نشان داد تعامل اين بيش آزمونها با متغير مستقل معنادار نبوده و ورون

$$
\text { ضرايب رگرسيون همخن بود. }
$$

بهاين ترتيب، با توجه به بررسى مفروضههاى آزمون تحليل كوواريانس جندمتغيرى و تأييد آنها، در ادامه نتايج مربوط به تأثير درمان مبتنى بر مدل شبيهازى ذهن بر ميزان استرس و انعطافيذيرى شناختى (و خرده مقياسهاى آن) در افراد مبتلابه لكنت با استفاده از آزمون تحليل كوواريانس جندمتغيرى آورده شده

$$
\text { است (جدول r). }
$$

با توجه به جدول زير، پِ از كنترل اثر ييش آزمونها،

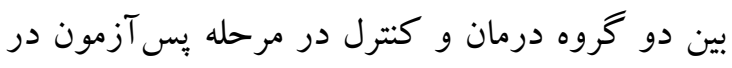
ميزان استرس و انعطافيذيرى شناختى اختلاف معنادارى وجود دارد. با توجه به ميانگين نمرات كسبشده كه بيشتر اشاره شد، مشخص مىشود كه درمان مبتنى بر مدل شبيهسازى ذهن در مقايسه با گروه كنترل، ميزان استرس افراد مبتلابه لكنت زبان را بهطور معنادارى كاهش (1...•

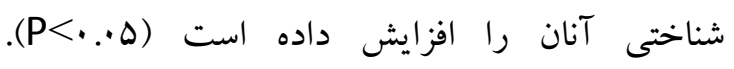
هم جنين، در مورد خرده مقياس هاى انعطاف يذيرى بايد

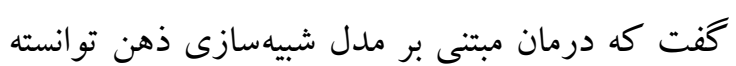

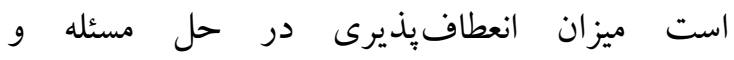
انعطاف يذيرى در تصميم گيرى افراد مبتلابه لكنت زبان را بهطور معنادارى افزايش دهد (ه •. •>P). باوجوداين،

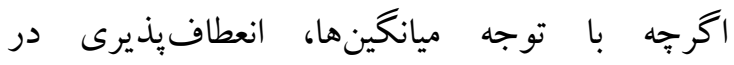
موقعيتهاى بيرونى افراد گروه آزمايش بِ بس از درمان مبتنى بر مدل شبيهسازى ذهن در مقايسه با گروه كنترل
حال، با توجه به طرح يثوهش حاضر كه از نوع ييش آزمون و بس آزمون است، براى تحليل دادهها و

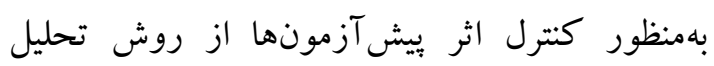

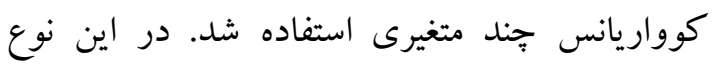

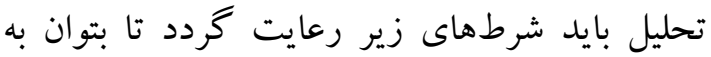
نتايج بهدست آمده اطمينان كرد: يكى از مفروضههاى آزمون تحليل كوواريانس جند متغيرى، نرمال بودن توزيع متغيرهاى وابسته است. با توجه به اينكه حجم نمونه در ئوهش حاضر كمتر از •ه نفر بود، جهت بررسى بيشفرض مذكور از آزمون شاييرو- ويلكك استفاده شد كه نتايج حاصل از آن، فرض صفر يعنى نرمال بودن متغيرهاى وابسته را تأييد

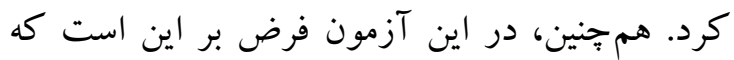

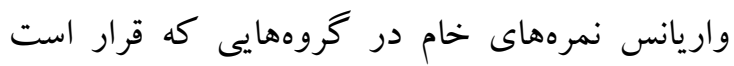
مورد تحليل قرار گيرند، تفاوت آمارى معنادارى با يكديگر ندارند. براى بررسى اين فرض از آزمون همخنى واريانس هاى لوين استفاده شد كه نتايج آن در بر بردي هيجيكك از متغيرهاى مورد بررسى ازلحاظ آمارى لهون

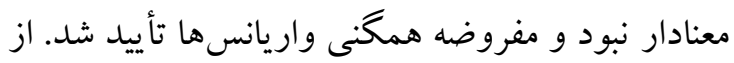
ديخر مفروضههاى آزمون تحليل كوواريانس جند مند متغيرى، همسانى ماتريسهاى واريانس - كوواريانس است. بدين منظور، از آزمون باكس 19 استفادهشده است. با توجه به آمارههاى حاصل از اين آزمون،

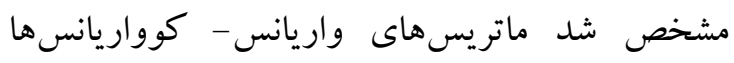
همخً هستند. علاوه براين، ديخر مفروضه مهم تحليل كوواريانس جند متغيرى، همخنى ضرايب رگرسيون (همخنى شيبها) است. لازم به ذكر است كه آزمون

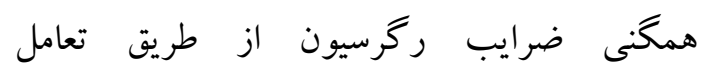

\footnotetext{
${ }^{19}$ Box's Test of Equality of Covariance Matrices
} 
افزايش داشته است، اما تغيير به وجود آمده ازنظر آمارى معنادار نيست.

جدول r. نتايج آزمون مانكووا مربوط به بررسى تأثير درمان مبتنى بر مدل شبيهسازى ذهن بر ميزان استرس و انعطاف يذيرى

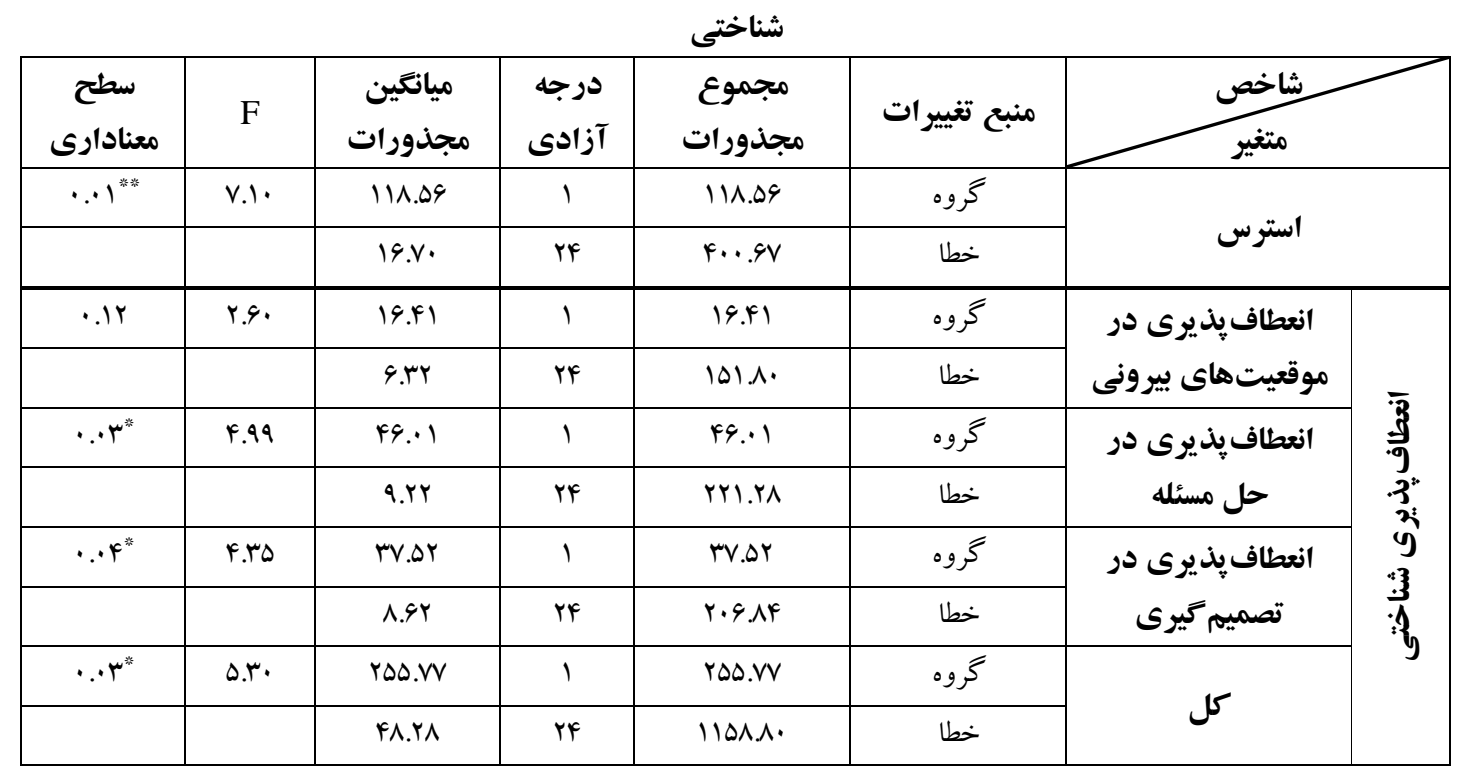

علامت

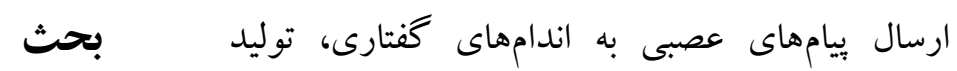
با توجه به نتايج بالا مىتوان كفت كه درمان مبتنى بر صوت و يايان يكك مرحله يا شروع واگويه هاى مدل شبيهسازى ذهن بر كاهش استرس و افزايش كفتارى صورت مى گيرد. هماهنگى بخش هاى مختلف

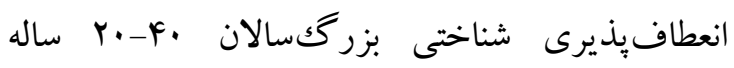
بدن براى كفتار نياز است و اين هماهنكى توسط ذهن مبتلابه لكنت زبان مؤثر بوده است. اين يافتهها با نتايج صورت مى گيرد. در حالت عادى يكك فرد آنقدر بايد يزوهشهاى تقىزاده و همكاران (تقىزاده و بيكدلى شاملو، a,b ه arا؛ تقىزاده و بيخدلى شاملو، 19 19؛ شير خدايى، تقىزاده و امينى خو (9 (1)؛ صانعى، تقىزاده و عبداله زاده، وهباן) كه نشان دادند مدل شبيهسازى ذهن مىتواند در درمان لكنت زبان و و

$$
\text { مشكلات همراه آن مؤثر افتد، هم سو است. }
$$

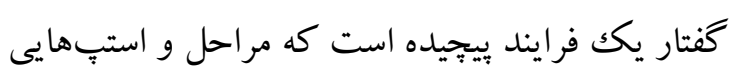
دارد و مانند تمامى رفتارها داراى الخوريتم مشخص است. عملكرد كفتار بر اساس الكوريتم محر كکهاى بيرونى و درونى، سامانه شناختى و ذهن، يردازش و تفسير اطلاعات، ارسال به سامانهاى عصبى و مغز، تمرين كند يا بهتر بكوييم برنامه ذهنى بسازد تا به برنامه

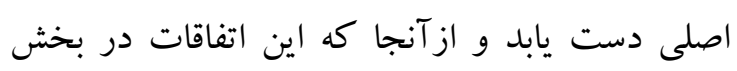
خود كار ذهن شكل مى گيرد، فرد دسترسى كاملى به اين برنامه نداشته و نمى تواند بهصورت آكاهانه آن را درك كند؛ بنابراين، بسيار دشوار است كه بتواند نواقص برنامه خود را بيداكرده و رفع كند (تقىزاده و

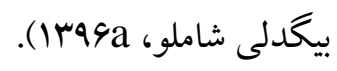
بر اساس مدل شبيه سازى ذهن، انسان مانند كامييوتر دو بعد سختافزار و نرمافزار دارد. مغز و بدن بعد سختافزارى ما و ذهن بعد نرمافزارى ما است. براى كنترل و ايجاد تغييرات در مغز و بدن بايد از ذهن 
شروع كرد؛ جايى كه فرمانها و دستورات را ساخته و به مغز ارسال مى كند و مغز هم با انتقال بيامهاى عصبى تركى به اندامها حر كات و رفتارهاى ما را مىسازد. در اين مدل با استفاده از زبان ذهن، برنامه ذهنى موجود فرد

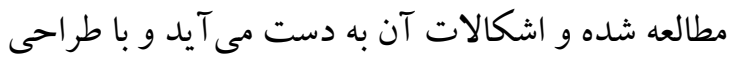
يكك برنامه جديد و كامل و انتقال آن به فرد در زمان كوتاهى مىتوان يك رفتار بييجيده را در فرد ايجاد

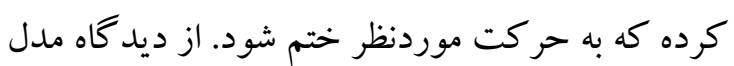
شبيهسازى ذهن، ريشه لكنت اختلال در ريتم، كاركرد كفتارى ذهن و همجينين اختلال در هماهنكى ذهن، زبان و بدن است. درواقع، برنامه و دستورات غلط ذهنى فرد باعث تغييرات در كاركرد مغز مىشود و فرد برد بهجاى استفاده از حنجره و كنترل صحيح آن، به قسمتهاى ديخرى (مانند ماهيجههاى حلقى، عضلات صورت، لبها، فك و غيره) نيرو وارد مى كند. حال بايد كارى كرد كه نيروها و كنترل از قسمتهاى ديخر برداشتهده و فقط تمركز روى حنجره ايجاد شود؛ بنابر اين، با تغيير برنامه ذهنى فرد به شكل طبيعى، سبك ولى

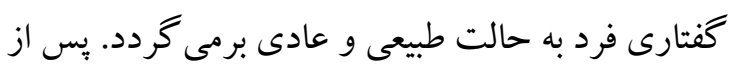
اجراى برنامه صحيح كفتارى، درمانجو بهراحتى مانند افراد عادى و به طرز طبيعى صحبت مى كند و اعلام مى كند كه فشارهاى فيزيكى او هنگام صحبت كاملاً رفع شده است (تقىزاده و بيخدلى شاملو، جنان كه بيزوهش حاضر نيز با بهره شبيهسازى ذهن نشان داد كه استفاده از اين درمان

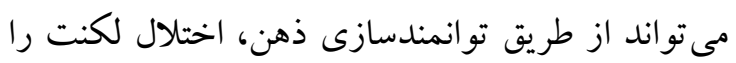
درمان كرده و مشكلات و مسائل همراه با آن را بهبود

بخشد. همسو با نتايج بثوهشهاى مبتنى بر دانش شبيهسازى

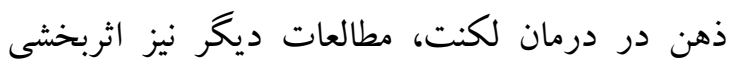
انواع شبيهسازى را در حيطههاى مختلف نشان دادهاند.
براى مثال، وودوارد ‘ (1991) در يُزوهشى به بررسى اثر يكك شبيهساز كامييوترى برافزايش مهارت حل مسئله و ياد كيرى دانش آموزان برداخت و نشان داد كه

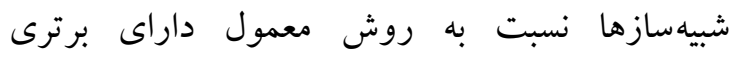

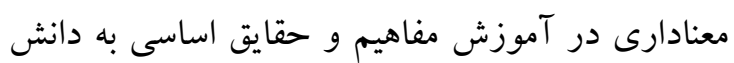
آموزان هستند، هم جنين در مقايسه روش آموزش مبتنى بر شبيهساز و روش معمول بر مهارت حل مسئله، تأثير كذارى روش مبتنى بر شبيهساز بيشتر بود. همجنين، خليلى شرفه، باكدامن و صدق يور (IMMA) در مطالعه خود با هدف ارزيابى تأثير شبيهسازىهاى ذهنى ساده و

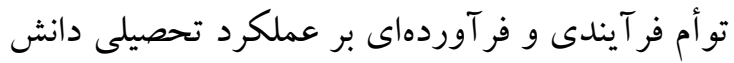
آموزان تيزهوش و عادى، نشان دادند كه شبيهسازى ذهنى با توجه به كنترل عامل هوش، به بهبود عملكرد

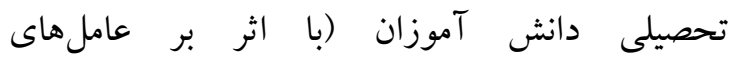
خود كار آمدى، برنامهريزى و انگيزش) مى مانجامد. پارسا، درتاج و صالح زاده كلور (•وس|) نيز در

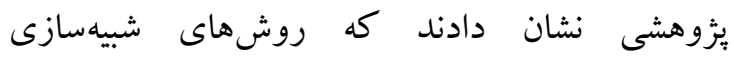
فرآوردهاى و همزمان مىتوانند تأثير معنادارى بر عملكرد تحصيلى و حافظه دانش آموزان داشته باشند

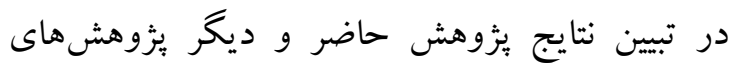
بركرفته از مدل شبيهسازى ذهن مىتوان اذعان داشت

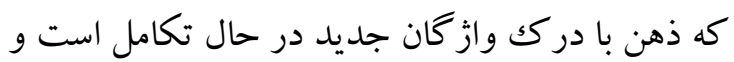
اين تكامل در مغز با رشد و تكامل عصبى يعنى ايجاد سينايسهاى جديد و توليد سلولهاى عصبى جديد در مغز همراه است كه اين ييشرفتها درنهايت مىتواند منجر به تغييرات در زنها شود. براى جندين سال، جنين تصور مىشد كه ارتباطهاى سينايس در مغز پِستانداران

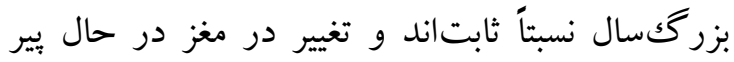
شدن عمدتاً براثر مرگك و تحليل رفتن سلول بيديد

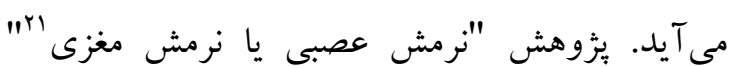

\footnotetext{
${ }^{20}$ Woodward

${ }^{21}$ brain plasticity or neuroplasticity
} 
اصطلاحى است كه براى توصيف توانايى مغز در باز سازماندهى يا تغيير ارتباطهايش براثر تجربه به كار

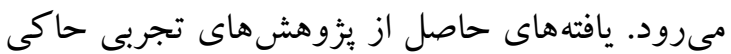

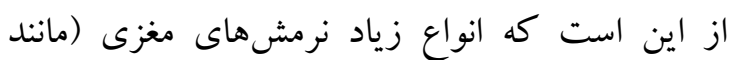
توانايى تحول دندريتها و تشكيل بيوندهاى سينايسى تازه در اثر تجربه محيطهاى غنى) در تمام دوره

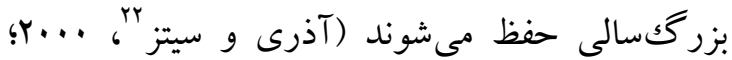

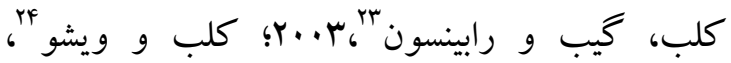

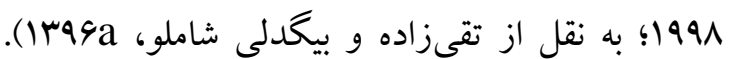

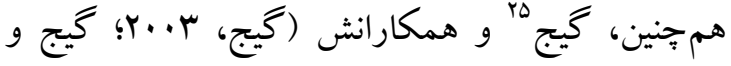

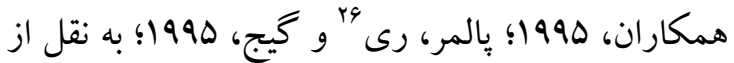

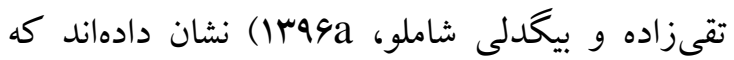

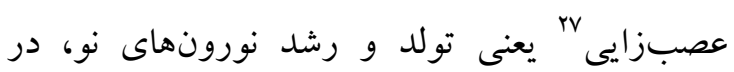
بخشهايى از مغز بسيارى از حيوانها، ازجمله انسان تا

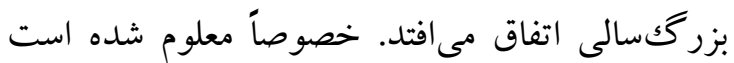
بخشهايى از شكنج دندانهاى هيبو كامٍ (كه در ياد گيرى و حافظه نقش دارند) و بخش هايى از ساختار

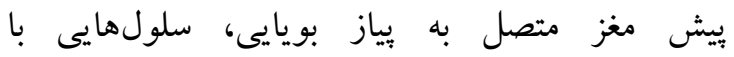
ويز گیىهاى تنه سلولى توليد مى كنند كه مىتوانند به به بيه نورون، كليا، يا حتى مويرگك تجزيه شوند؛ يعنى اينكه، دست كم يكك قسمت از مغز كه براى يادگيرى حياتى

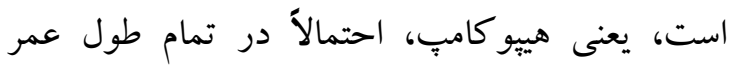

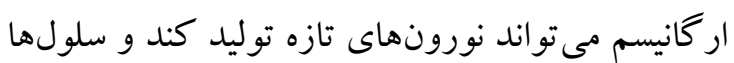
را مورد حمايت قرار دهد. همان گونه كه ييشتر اشاره شد، تقىزاده و همكاران (تقىزاده و بيخدلى شاملو، ههa,b خدايى، تقىزاده و امينىخو، وه؟1! صانعى، تقىزاده و

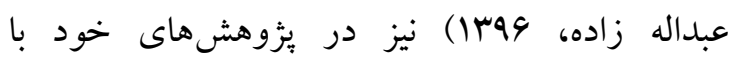
به كار گيرى مدل شبيهازى ذهن نشان دادهاند انسان

\footnotetext{
${ }^{22}$ Azari \& Seitz

${ }^{23}$ Kolb, Gibb \& Robinson

${ }^{24}$ Whishaw

${ }^{25}$ Gage

${ }^{26}$ Palmer, \& Ray

${ }^{27}$ neuron genesis
}

موجودى منعطف و قابلتغيير و توسعه است و بهجز مواردى كه مغز و بدن دهار آسيبهاى جدى شدهاند، محدوديتى براى رشد انسان وجود ندارد و مىتوان با بإن ايجاد محيطهاى بيجيده و گسترش خلاقيتهاى ذهنى، باعث توسعه و بيشرفت در كفتار او شد. در آخر، بايد اذعان ساخت كه بثزوهش حاضر نيز مانند بسيارى از تحقيقات، با محدوديتهاى ويزه خود روبرو بوده است. براى مثال، محدود بودن نمونه يُزوهش در

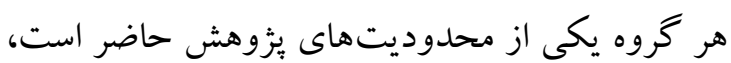
بلهويزه زمانى كه افرادى از هر دو جنس در فرايند يثزوهش شركت داشتند كه امكان تمايز نتايج بر اين مبنا را فراهم نمىساخت. نمونه بُزوهش حاضر متشكل از

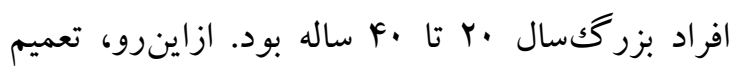
يافتهاى حاصل از يزوهش حاضر به ساير گروههاى سنى بايد با احتياط صورت يذيرد. همجنين، يزوهش

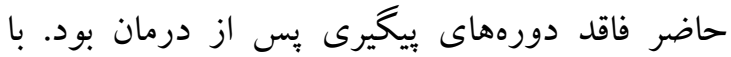
توجه به محدوديتهاى ذكرشده، بهمنظور فراهم شدن امكان مقايسه نتايج و سنجش ميزان يايدارى اثرات درمانى، بيشنهاد مىشود يُزوهشهاى آتى مربوط به

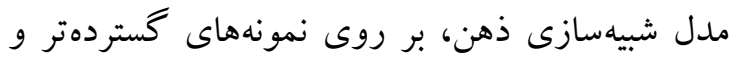

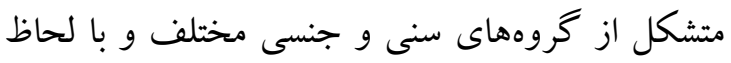
نمودن دورههاى بيگيرى متفاوت در طول زمان انجام

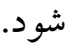

\section{نتيجه كيرى}

با توجه به نتايج يزوهش حيرى حاضر و ديخر يزوهشهاى

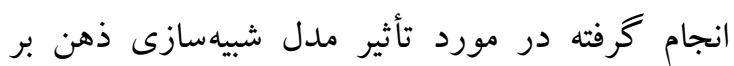
اختلال لكنت، مىتوان كفت كه استفاده از اين روش نوين مىتواند به گونهاى مؤثر، ما را در درمان اختلال

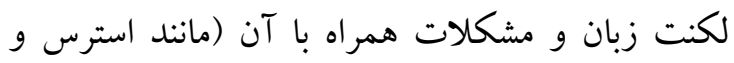
نقص در انعطافيذيرى شناختى) در بزرگك سالان

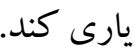


Delavar, A. (2012). Educational and Psychological Research, 4th rivised. Tehran: Virayesh Publication Institute.

Dennis, J. P., \& Vander Wal, J. S. (2010). The cognitive flexibility inventory: Instrument development and estimates of reliability and validity. Cognitive Therapy Research, 34, 241-253.

Doneva, S., Davis, S., \& Cavenagh, P. (2017). Comparing the performance of people who stutter and people who do not stutter on the Test of Everyday Attention. Journal of clinical and experimental neuropsychology, 1-15.

Eichom, N., Marton, K., \& Pinutinsky, S. (2017). Cognitive flexibility in preschool children with and without stuttering disorders. Joumal of fluency disorders.

Farazi, M., Gholami Tehrani, L., Khodabakhshi Kolaee, A., Shemshadi, H. \& Rahgozar, M. (2014). The effect of a combination of cognitive therapy and speech in stutterers. Thought \& Behavior in Clinical Psychology, 8 (30), 37-46. (Persian)

Gage, F. H. (2003). Brain, repair yourself. Scientific American, 289(3), 46-53.

Gage, F. H., Coates, P. W., Palmer, T. D., Kuhn, H. G., Fisher, L. J., Suhonen, J. O., ... \& Ray, J. (1995). Survival and differentiation of adult neuronal progenitor cells transplanted to the adult brain. Proceedings of the National Academy of Sciences, 92(25), 11879-11883.

Guitar, B. (2006). Stuttering: an integreted approach to its nature and treatment. $3^{\text {rd }}$ ed. Publication: lippincott Williams and Wilkins publ.

Iverach,L., Jones, M., McLellan, L. F., Lyneham, H. J., Menzies, R.G., Onslow, M., Rapee, R. M. (2016). Prevalence of anxiety disorders among children who stutter. Journal of Fluency Disorders, 49, 13-28

Jacques, S., \& Zelazo, P. D. (2005). On the possible roots of cognitive flexibility

Kakoee, F., Arani- Kashani, Z, Kamali, M., \& Jan Bozorgi, M. (2016). Social phobia and its relation to demographic characteristics in adults with stuttering disorder. Iranian Joumal of Psychiatric and Clinical Psychology, 21 (4), 362-369. (Persian)

Kempermann, G., Gast, D., Kronenberg, G., Yamaguchi, M., \& Gage, F. H. (2003). Early determination and long-term persistence of adultgenerated new neurons in the hippocampus of mice. Development, 130(2), 391-399.

Khalili, S.F., Pakdaman, S., \& Saleh, S. B. (2009). The effect of simple and both process and product mental

$$
\begin{aligned}
& \text { سياسگزارى } \\
& \text { يُزوهشخران بر خود لازم مىدانند از همكارى تمام } \\
& \text { عزيزانى كه با كشادهرويى در اين تحقيق شركت برد } \\
& \text { كردند و همجينين از كار كنان كلينيك توانمند سازان } \\
& \text { ذهن كه ما را در اجراى اين يُزوهش يارى رساندند، } \\
& \text { صميمانه تشكر و سباسگز ارى نمايند. }
\end{aligned}
$$

\section{References}

Ahadi, B., Sotoodeh, M. B., \& Habibi, Y. (2013). Comparing psychological well-being and defense mechanisms in students with and without stuttering. Joumal of school psychology, 1 (4), 6-22. (Persian)

American Psychiatric Association (2013). Diagnostic and Statistical Manual of Mental Disorders (DSM-5). Translated by Rezaee. F. and other (2015). Tehran: Arjmand publication. (Persian)

Azari, N. P., \& Seitz, R. J. (2000). Brain Plasticity and Recovery from Stroke: What has changed in the brain of a stroke patient who recovers the ability to move a once-disabled limb?. American Scientist, 88 (5), 426-431.

Bahrami, H., Nejati, V., \& Pooretemad, H. (2014). A Comparative Study of Phonemic and Semantic Verbal Fluency in Children and Adolescents with Developmental Stuttering.Zahedan Joumal of Research in Medical Sciences, 16(5), 41-44.

Behrozi, N., Shahni Yeylagh, M., \& Pour Saeed, S. M. (2013). The relationship of perfectionism, perceived stress and social support with academic burnout. Strategy of culture, 5 (20), 83-102. (Persian)

Berk, L. (2007). Development through the lifespan, 4th edition, translated by Seyed-Mohammadi, Y. (2012). Tehran: Arasbaran publication. (Persian)

Cohen,S., Kamarck,T., \& Mermelstein,R. (1983). A global measure of perceived stress. Joumal of Health and Social Behavior, 24, 385-396.

simulation on academic performance of ordinary and gifted students. Educational and Psychological Journal, 5 (1), 23-42. (Persian)

Kolb, B., \& Whishaw, I. Q. (1998). Brain plasticity and behavior. Annual review of psychology, 49(1), 43-64.

Kolb, B., Gibb, R., \& Robinson, T. E. (2003). Brain plasticity and behavior.Cument Directions in Psychological Science, 12(1), 1-5. 
Palmer, T. D., Ray, J., \& Gage, F. H. (1995). FGF-2responsive neuronal progenitors reside in proliferative and quiescent regions of the adult rodent brain. Molecular and Cellular Neuroscience, 6(5), $474-486$.

Parsa, A., Dortaj, F., \& Salehzadeh, K. S. (2011). Investigation the effect of process, product and mixed mental simulation on memory and academic performance improvement in high school students. The first national conference on cognitive science in education and training. (Persian)

Sanei, N., Taghizadeh, M., E., \& Abdollah Zadeh, H. (2017). ). The study of effectiveness of mind simulation model on emotion regulation and positive thinking in 20-40 years old people with stuttering disorder. Master's Thesis, Payame- Noor University. Behshahr branch (Persian)

Shir- Khodaee, Z., Taghizadeh, M., E., \& Amini-Khoo, M. (2017). The study of effectiveness of mind simulation model on reduce the fear of verbal communication and self- confidence enforcement in 20-30 years old men with stuttering disorder. Master's Thesis, Azad Islamic University, Tehran branch. (Persian)

Taghizadeh, M., E., \& Bigdeli, S. M. (2016). Simulation of the mind and its role in deterministic and imeversible treatment of stuttering, Department of Psychology, Payame Noor University (PNU), Tehran, Iran, 8 (1):85-89.

Taghizadeh, M., E., \& Bigdeli, S. M. (2016a). The Effectiveness of Stuttering Therapy Using Mind Simulation. 3th Intemational Conference on Recent Innovations in Psychology, Counseling and Behavioral Sciences, Tehran: Iran. PSYCHO03_285. (Persian)
Taghizadeh, M., E., \& Bigdeli, S. M. (2016b).Effectiveness of mind simulation model of Mohammad Ehsan (MSMMET) on treatment of stuttering of individuals between 20 and 39 years, Scholar Research Library, 8(1):415-418. (Persian)

Taghizadeh, M., E., \& Bigdeli, S. M. (2017a). Speech Algorithm and Speech Creativity in Human. 4th Intemational Conference on Recent innovations in psychology, counseling and behavioral sciences. (Persian)

Taghizadeh, M., E., \& Bigdeli, S. M. (2017b). The role of coding and programming of mind in controlling and changing the brain and body. 4th Intemational Conference on Recent innovations in psychology, counseling and behavioral sciences. (Persian)

Taghizadeh, M., E., \& Farmani, A. (2014). A Study of the Role of Cognitive Flexibility in Predicting Hopelessness and Resilience among University Students. Journal of Cognitive Psychology, 1 (2). (Persian)

Toozandehjani, H., Naaimi, H., Ahmadpoor, M. (2011). An investigation on the efficacy of confrontation cognitivebehavioral skills through group training on the anxiety and adjustment of children with stuttering. Research in rehabilitation science, 7 (2). (Persian)

Woodward, J., Carmine, D., \& Germen, R. (1998). Teaching problem solving through computer simulations. American educational research joumal, Vol 25, No 1, p72-86.

Zamani, P., \& Latifi, S. M. (2011). The efficacy of prolonged speech technique in boys with mild stuttering, Joumal of Shahrekord University of Medical Sciences, 13(5): 20-26.(Persian) 